\title{
ANALISIS PERSEPSI PELAJAR TINGKAT MENENGAH PADA SEKOLAH TINGGI AGAMA ISLAM NEGERI KUDUS
}

\author{
Rofiq Faudy Akbar \\ STAIN Kudus, Jawa Tengah, Indonesia. \\ rofiqfa@gmail.com
}

\begin{abstract}
Abstrak
Persepsi adalah pandangan secara umum atau global mengenai suatu obyek dilihat dari beberapa aspek yang dapat difahami oleh seseorang. Mengetahui persepsi masyarakat terhadap suatu lembaga pendidikan merupakan upaya untuk melihat keinginan atau ekspektasi masyarakat terhadap lembaga tersebut. Perguruan tinggi sebagai lembaga sosial yang tumbuh dan berkembang untuk masyarakat tidak terlepas dari target yang dibutuhkan oleh masyarakat itu sendiri. Penelitian ini dilakukan untuk mengetahui persepsi masyarakat terhadap STAIN Kudus. Masyarakat dalam penelitian ini dikhususkan pada pelajar tingkat menengah dari Madrasah Aliyah dan Sekolah Menengah Atas. Pendekatan dalam penelitian ini adalah pendekatan kuantitatif karena penelitian ini disajikan dengan angka, tabel dan diagram. Hasil dari penelitian ini menunjukkan bahwa terdapat beberapa faktor yang mempengaruhi perbedaan persepsi pelajar Madrasah Aliyah dan Sekolah Menengah Atas terhadap STAIN Kudus.
\end{abstract}

Kata kunci: Persepsi, Pelajar, STAIN Kudus

\begin{abstract}
HIGH SCHOOL STUDENTS' PERSCEPTION ANALYSIS TO STATE ISLAMIC COLLEGE OF KUDUS (STAIN KUDUS). Perception is a general or global view on an object viewed from several
\end{abstract}


aspects that can be understood by someone. Knowing the public perception of an educational institution is an attempt to see the public desire or expectation of the institution. University as social institution which grows and develops for society can not be separated from the target required by the community itself. This study is conducted to know the public perception of STAIN Kudus. The society in this study is devoted to students of Madrasah Aliyah and senior high school. The study uses quantitative approach because this study is presented in numbers, tables, and diagram. This study show that there are some factor which influence the perception differences between Madrasah Aliyah and Senior Hight School Student to STAIN Kudus.

Keywords: perception, student, STAIN Kudus

\section{A. Pendahuluan}

Perguruan tinggi merupakan satuan pendidikan yang menyelenggarakan pendidikan tinggi. Menurut jenisnya, perguruan tinggi dibagi menjadi dua yaitu: perguruan tinggi negeri, perguruan tinggi yang diselenggarakan oleh pemerintah dan perguruan tinggi swasta, perguruan tinggi yang diselenggarakan oleh pihak swasta. Di Indonesia, perguruan tinggi dapat berbentuk akademi, institut, politeknik, sekolah tinggi maupun universitas. Perguruan tinggi dapat menyelenggarakan pendidikan akademik, profesi, dan vokasi dengan program pendidikan dari jenjang diploma (D1, D2, D3, D4), sarjana (S1), magister (S2), doktor (S3), dan spesialis. Perguruan tinggi baik negeri maupun swasta memiliki tanggung jawab besar dalam menghasilkan lulusan-lulusan yang memiliki bekal pengetahuan dan ketrampilan.

Sebagaimana yang diamanatkan dalam UU No. 12 tahun 2012 tentang Pendidikan Tinggi, sebagai bagian dari sistem pendidikan nasional pendidikan tinggi memiliki peran strategis dalam mencerdaskan kehidupan bangsa dan memajukan ilmu pengetahuan dan teknologi dengan memperhatikan dan menerapkan nilai humaniora serta pembudayaan dan pemberdayaan bangsa Indonesia yang berkelanjutan. Demikian pula untuk menghadapi globalisasi manusia-manusia Indonesia perlu peningkatan daya saing di berbagai bidang. Perguruan tinggi diharapkan mampu mengembangkan ilmu pengetahuan dan teknologi serta menghasilkan intelektual, ilmuan atau professional yang berbudaya dan kreatif, toleran, demokratis, 
Analisis Persepsi Pelajar Tingkat Menengah Pada Sekolah Tinggi Agama Islam

berkarakter, tangguh serta berani membela kebenaran untuk kepentingan bangsa.

Pendidikan merupakan faktor yang sangat penting bagi masyarakat, pendidikan memiliki kontribusi terhadap kemajuan dan kemunduran suatu masyarakat atau bangsa. Dengan pendidikan pola kehidupan masyarakat dapat berubah dari terbelakang kemudian menjadi lebih baik dan beradab. Melalui pendidikan pula kelangsungan hidup suatu bangsa dapat dipertahankan. Menimbang sangat pentingnya pendidikan bagi masyarakat, kemajuan sektor pendidikan tidak lepas dari peran dan kontribusi bersama antara pemerintah, lembaga pendidikan dan masyarakat. Ketiga-tiganya harus sepemahaman dalam menjalankan dan mengawal pelaksanaan pendidikan yang ada. Pemerintah sebagai fasilitator penyelenggara pendidikan, memiliki peran sentral dalam menentukan garis-garis besar pendidikan yang dijalankan dan memfasilitasi pelaksanaannya. Lembaga pendidikan sebagai pelaksana memiliki keleluasaan mengatur, memanajemen dan mengembangkan ilmu pengetahuan dan pengajaran. Adapun masyarakat memiliki peran dalam mengawal penyelenggaraan pendidikan, agar pendidikan yang ada benar-benar telah dibutuhkan serta memberikan efek positif secara luas.

Dari sini, lembaga pendidikan khususnya pendidikan tinggi harus pro aktif dalam menjalin hubungan baik dengan pemerintah maupun masyarakat. Menyampaikan ide-ide mengenai pengembangan pendidikan kepada pemerintah dan menjaring aspirasi serta mengetahui persepsi dan keinginan masyarakat mengenai program pendidikan yang dilaksanakan. Perguruan tinggi sebagai lembaga teratas dalam pelaksanaan pendidikan harus responsif terhadap keinginan masyarakat. Mengetahui keinginan masyarakat adalah suatu hal yang penting untuk dilakukan dikarenakan masyarakat adalah pelanggan dan pemakai pendidikan serta produk-produknya. Persepsi masyarakat terhadap perguruan tinggi merupakan gambaran secara global mengenai keinginan atau ekspektasi dan penilaian terhadap produk yang dihasilkan dari pelaksanaan pendidikan. Walaupun kadang persepsi yang diberikan sedikit berbeda dengan kenyataan yang ada, namun mengetahui persepsi masyarakat, minimal dapat memberikan arah terhadap 
perbaikan dan perkembangan lembaga pendidikan yang dalam hal ini adalah perguruan tinggi.

Persepsi dapat dikatakan sebagai sebuah proses masuknya pesan atau informasi ke dalam otak manusia yang terintegrasi dengan pikiran, perasaan, dan pengalaman-pengalaman individu. Social learning theory memandang bahwa perilaku individu tidak semata-mata reflek otomatis atau stimulus, melainkan juga akibat reaksi yang timbul sebagai hasil interaksi antara lingkungan dengan skema kognitif individu itu sendiri. Gibson, dkk (1989) dalam buku Organisasi dan Manajemen Perilaku, Struktur; memberikan definisi persepsi sebagai proses kognitif yang dipergunakan oleh individu untuk menafsirkan dan memahami dunia sekitarnya (terhadap objek). Gibson juga menjelaskan bahwa persepsi merupakan proses pemberian arti terhadap lingkungan oleh individu. Oleh karena itu, setiap individu memberikan arti kepada stimulus secara berbeda meskipun objeknya sama.

Cara individu melihat situasi seringkali lebih penting daripada situasi itu sendiri. Persepsi adalah pandangan secara umum atau global mengenai suatu obyek dilihat dari beberapa aspek yang dapat difahami oleh seseorang. Persepsi adalah anggapan berdasarkan pengalaman atau pengetahuan yang kadang berbeda antara satu orang dengan orang lain atau kadang berbeda dengan kondisi yang sebenarnya. mengetahui persepsi masyarakat terhadap suatu lembaga pendidikan merupakan upaya untuk melihat keinginan atau ekspektasi masyarakat terhadap lembaga tersebut. Perguruan tinggi sebagai lembaga sosial yang tumbuh dan berkembang dari dan untuk masyarakat tidak terlepas dari target dan sasaran yang dibutuhkan oleh masyarakat itu sendiri, sehingga perguruan tinggi yang memenuhi target dan sasaran tersebut akan selalu di cari oleh masyarakat. Terlebih ketika disisi lain terdapat adanya persepsi yang menyatakan bahwa pendidikan belum mampu memberikan jaminan tentang masa depan. Hal ini dilihat dari banyaknya para lulusan perguruan tinggi yang tidak dapat memberikan peran secara optimal di tengah-tengah masyarakat.

Berangkat dari permasalahan diatas, penelitian ini dilakukan untuk mengetahui mengenai persepsi masyarakat terhadap Sekolah Tinggi Agama Islam Negeri Kudus. Masyarakat dalam penelitian 
Analisis Persepsi Pelajar Tingkat Menengah Pada Sekolah Tinggi Agama Islam

ini dikhususkan pada pelajar tingkat menengah dari Madrasah Aliyah dan Sekolah Menengah Atas. Alasan peneliti mengkhususkan objek penelitian, adalah karena pelajar tingkat menengah secara langsung akan memanfaatkan jasa perguruan tinggi setelah mereka menyelesaikan studi pada tingkat menengah. Persepsi mereka terhadap perguruan tinggi akan mempengaruhi pilihan dalam melanjutkan studi.

Pendekatan dalam penelitian ini adalah pendekatan kuantitatif, karena penelitian ini disajikan dengan angka-angka. Hal ini sesuai dengan pendapat (Arikunto 2006: 12)yang mengemukakan penelitian kuantitatif adalah pendekatan penelitian yang banyak dituntut menguakan angka, mulai dari pengumpulan data, penafsiran terhadap data tersebut, serta penampilan hasilnya.

\section{B. Pembahasan}

\section{Kajian Teori}

\section{a. Pengertian persepsi}

Kata persepsi berasal dari Bahasa Inggris, perception yang artinya: persepsi, penglihatan, tanggapan. Adapun dalam Kamus Besar Bahasa Indonesia, persepsi diintepretasikan sebagai tanggapan atau penerimaan langsung dari sesuatu, atau proses seseorang mengetahui beberapa hal melalui panca inderanya (Yufid, KBBI elektronik). Persepsi merupakan hal yang mempengaruhi sikap, dan sikap akan menentukan perilaku.

Dengan kata lain dapat disimpulkan bahwa persepsi mempengaruhi perilaku seseorang atau perilaku merupakan cermin persepsi yang dimilikinya. Persepsi adalah tanggapan atau gambaran langsung dari suatu serapan seseorang dalam mengetahui beberapa hal melalui panca indera. Dalam pengertian ini jelas, bahwa persepsi adalah kesan gambaran atau tanggapan yang dimiliki seseorang setelah orang tersebut menyerap untuk mengetahui beberapa hal (objek), melalui panca indera.

\section{b. Terbentuknya persepsi}

Persepsi merupakan suatu proses yang diawali oleh penginderaan. Penginderaan adalah merupakan suatu proses diterimanya stimulus oleh individu melalui alat penerima yaitu alat indera. Pada umumnya stimulus tersebut diteruskan saraf ke otak 
sebagai pusat susunan saraf dan proses selanjutnya merupakan proses persepsi. Stimulus diterima oleh alat indera, kemudian melalui proses persepsi sesuatu yang diindera tersebut menjadi sesuatu yang berarti setelah diorganisasikan dan diinterpretasikan (Walgito, 2002: 53). Sehingga dapat dikemukakan bahwa persepsi itu merupakan proses pengorganisasian, penginter-pretasikan terhadap stimulus yang diterima oleh organisme atau individu sehingga merupakan sesuatu yang berarti, dan merupakan aktivitas yang integrated dalam diri individu.

Walgito (2010: 53) mengungkapkan bahwa persepsi merupakan suatu proses pengorganisasian, penginterpretasian terhadap stimulus yang diterima oleh organisme atau individu sehingga menjadi sesuatu yang berarti, dan merupakan aktivitas yang integrated dalam diri individu. Respon sebagai akibat dari persepsi dapat diambil oleh individu dengan berbagai macam bentuk. Stimulus mana yang akan mendapatkan respon dari individu tergantung pada perhatian individu yang bersangkutan. Berdasarkan hal tersebut, perasaan, kemampuan berfikir, pengalaman-pengalaman yang dimiliki individu tidak sama, maka dalam mempersepsi sesuatu stimulus, hasil persepsi mungkin akan berbeda antar individu satu dengan individu lain.

Walgito juga menambahkan, bahwa persepsi adalah suatu kesan terhadap suatu objek yang diperoleh melalui proses penginderaan, pengorganisasian, dan interpretasi terhadap obyek tersebut yang diterima oleh individu, sehingga merupakan suatu yang berarti dan merupakan aktivitas integrated dalam diri individu. Pendapat ini tidak bertentangan dengan pendapat sebelumnya, tetapi justru lebih menjelaskan proses terjadinya yaitu setelah penyerapan maka gambaran-gambaran yang diperoleh lewat panca indera itu kemudian diorganisir, kemudian diinterpretasi (ditafsirkan) sehingga mempunyai arti atau makna bagi individu, sedang proses terjadinya persepsi tersebut merupakan satu kesatuan aktifitas dalam diri individu.

Adapun menurut Robbins (2007:175), persepsi adalah sebuah proses saat individu mengatur dan menginterpretasikan kesan-kesan sensoris mereka guna memberikan arti bagi lingkungan mereka. Perilaku individu seringkali didasarkan pada persepsi mereka 
tentang kenyataan, bukan pada kenyataan itu sendiri. Istilah persepsi sering dikacaukan dengan sensasi. Sensasi hanya berupa kesan sesaat, saat stimulus baru diterima otak dan belum diorganisasikan dengan stimulus lainnya dan ingatan-ingatan yang berhubungan dengan stimulus tersebut. Sebagai misal meja yang terasa kasar, yang berarti sebuah sensasi dari rabaan terhadap meja. Sebaliknya persepsi memiliki contoh meja yang tidak enak dipakai menulis, saat otak mendapat stimulus rabaan meja yang kasar, penglihatan atas meja yang banyak coretan, dan kenangan di masa lalu saat memakai meja yang mirip lalu tulisan menjadi jelek.

Menurut Davidoff, persepsi merupakan cara kerja atau proses yang rumit dan aktif, karena tergantung pada sistem sensorik dan otak (Davidoff, 1988: 273). Bagi manusia, persepsi merupakan suatu kegiatan yang fleksibel, yang dapat menyesuaikan diri secara baik terhadap masukan yang berubah-ubah. Dalam kehidupan seharihari, tampak bahwa persepsi manusia mempunyai kemampuan menyesuaikan diri dengan baik terhadap lingkungan dan budayanya. Dalam konteks ini, pengalaman-pengalaman pada berbagai kebudayaan yang berbeda dapat mempengaruhi bagaimana informasi penglihatan itu diproses.

\section{c. Faktor-Faktor Persepsi}

Adapun faktor-faktor yang berperan dalam persepsi menurut Walgito antara lain:

1) Objek yang dipersepsi

Objek menimbulkan stimulus yang mengenai alat indera atau reseptor. Stimulus dapat datang dari luar individu yang mempersepsi, tetapi juga dapat datang dari dalam diri individu yang bersangkutan yang langsung mengenai syaraf penerima yang bekerja sebagai reseptor.

2) Alat indera, syaraf dan susunan syaraf

Alat indera atau reseptor merupakan alat untuk menerima stimulus, di samping itu juga harus ada syaraf sensoris sebagai alat untuk meneruskan stimulus yang diterima reseptor ke pusat susunan syaraf, yaitu otak sebagai pusat kesadaran. Sebagai alat untuk mengadakan respon diperlukan motoris yang dapat membentuk persepsi seseorang. 
Rofiq Faudy Akbar

3) Perhatian

Untuk menyadari atau dalam mengadakan persepsi diperlukan adanya perhatian, yaitu merupakan langkah utama sebagai suatu persiapan dalam rangka mengadakan persepsi. Perhatian merupakan pemusatan atau konsentrasi dari seluruh aktivitas individu yang ditujukan kepada sesuatu sekumpulan objek.

Faktor-faktor tersebut menjadikan persepsi individu berbeda satu sama lain dan akan berpengaruh pada individu dalam mempersepsi suatu objek, stimulus, meskipun objek tersebut benarbenar sama. Persepsi seseorang atau kelompok dapat jauh berbeda dengan persepsi orang atau kelompok lain sekalipun situasinya sama. Perbedaan persepsi dapat ditelusuri pada adanya perbedaanperbedaan individu, perbedaan- perbedaan dalam kepribadian, perbedaan dalam sikap atau perbedaan dalam motivasi. Pada dasarnya proses terbentuknya persepsi ini terjadi dalam diri seseorang, namun persepsi juga dipengaruhi oleh pengalaman, proses belajar, dan pengetahuannya.

\section{d. Indikator persepsi}

Persepsi merupakan kesan yang diperoleh oleh individu melalui panca indera kemudian di analisis (diorganisir), diintepretasi dan kemudian dievaluasi, sehingga individu tersebut memperoleh makna. Pendapat Robbins lebih melengkapi pendapat-pendapat sebelumnya, yaitu adanya unsur -unsur evaluasi atau penilaian terhadap obyek persepsi. Robbins menetapkan indikator-indikator persepsi menjadi dua macam, yaitu:

1) Penerimaan

Proses penerimaan merupakan indikator terjadinya persepsi dalam tahap fisiologis, yaitu berfungsinya indera untuk menangkap rangsang dari luar.

2) Evaluasi

Rangsang-rangsang dari luar yang telah ditangkap indera, kemudian dievaluasi oleh individu. Evaluasi ini sangat subjektif. Individu yang satu menilai suatu rangsang sebagai sesuatu yang sulit dan membosankan. Tetapi individu yang lain menilai rangsang yang sama tersebut sebagai sesuatu yang bagus dan menyenangkan.

Sedangkan indikator persepsi menurut Bimo Walgito antara lain: 
1) Penyerapan terhadap rangsang atau objek dari luar individu Rangsang atau objek tersebut diserap atau diterima oleh panca indera, baik penglihatan, pendengaran, peraba, pencium, dan pengecap secara sendiri-sendiri maupun bersama-sama. Dari hasil penyerapan atau penerimaan oleh alat-alat indera tersebut akan mendapatkan gambaran, tanggapan, atau kesan di dalam otak. Gambaran tersebut dapat tunggal maupun jamak, tergantung objek persepsi yang diamati. Di dalam otak terkumpul gambarangambaran atau kesan-kesan, baik yang lama maupun yang baru saja terbentuk. Jelas tidaknya gambaran tersebut tergantung dari jelas tidaknya rangsang, normalitas alat indera dan waktu, baru saja atau sudah lama.

2) Pengertian atau pemahaman

Setelah terjadi gambaran-gambaran atau kesan-kesan di dalam otak, maka gambaran tersebut diorganisir, digolonggolongkan (diklasifikasi), dibandingkan, diinterpretasi, sehingga terbentuk pengertian atau pemahaman. Proses terjadinya pengertian atau pema-haman tersebut sangat unik dan cepat. Pengertian yang terbentuk tergantung juga pada gambaran-gambaran lama yang telah dimiliki individu sebelumnya (disebut apersepsi).

3) Penilaian atau evaluasi

Setelah terbentuk pengertian atau pemahaman, terjadilah penilaian dari individu. Individu membandingkan pengertian atau pemahaman yang baru diperoleh tersebut dengan kriteria atau norma yang dimiliki individu secara subjektif. Penilaian individu berbeda-beda meskipun objeknya sama, oleh karena itu persepsi bersifat individual.

Melalui persepsi individu dapat menyadari, dapat mengerti tentang keadaan diri individu yang bersangkutan. Persepsi itu merupakan aktivitas yang integrated, maka seluruh apa yang ada dalam diri individu seperti perasaan, pengalaman, kemampuan berpikir, kerangka acuan dan aspek-aspek lain yang ada dalam diri individu masyarakat akan ikut berperan dalam persepsi tersebut (Walgito, 2010: 99). Berdasarkan atas hal tersebut, dapat dikemukakan bahwa dalam persepsi itu sekalipun stimulusnya sama tetapi karena pengalaman tidak sama, kemampuan berpikir tidak sama, kerangka acuan tidak sama, adanya kemungkinan hasil persepsi 
antara individu dengan individu yang lain tidak sama.

Kebudayaan merupakan sesuatu yang berhubungan erat dengan perilaku manusia dan kepercayaan, maka ia meliputi berbagai hal dalam kehidupan manusia, yang diantaranya adalah agama, pendidikan, struktur sosial ekonomi, pola kekeluargaan, kebiasaan mendidik anak, dan sebagainya. Kondisi kehidupan seseorang sehari-harinya sangat mempengaruhi persepsi pada setiap peristiwa sosial, dimana dalam setiap kegiatan sosial tersebut selalu melibatkan hubungan antar subjek dan terbentuknya makna. Makna tersebut akan menentukan kesanggupan seseorang untuk terlibat dan berpartisipasi pada kegiatan tertentu dalam masyarakatnya (Sutopo, 1996: 133).

Persepsi selalu berkaitan dengan pengalaman dan tujuan seseorang pada waktu terjadinya proses persepsi. Ia merupakan tingkah laku selektif, bertujuan, dan merupakan proses pencapaian makna, dimana pengalaman merupakan faktor penting yang menentukan hasil persepsi (Sutopo, 1996: 133). Tingkah laku selalu didasarkan pada makna sebagai hasil persepsi terhadap kehidupan para pelakunya. Apa yang dilakukan, dan mengapa seseorang melakukan berbagai hal, selalu didasarkan pada batasan-batasan menurut pendapatnya sendiri, dan dipengaruhi oleh latar belakang budayanya yang khusus (Spradle, 1980: 137). Budaya yang berbeda, melatih orang secara berbeda pula dalam menangkap makna suatu persepsi, karena kebudayaan merupakan cara khusus yang membentuk pikiran dan pandangan manusia.

Dari teori-teori di atas, dapat dikemukakan bahwa persepsi merupakan proses dimana individu-individu memperoleh anggapananggapan sebagai hasil interpretasi dari objek yang diamatinya secara selektif. Persepsi merupakan dinamika respon yang terjadi dalam diri seseorang ketika menerima rangsangan dari luar melalui panca indra, dan dipengaruhi oleh faktor pengetahuan, pengalaman, emosional, serta aspek kepribadian. Dari sini indivudu akan menentukan persepsi apakah suatu objek tersebut baik atau buruk, berguna atau tidak berguna, penting atau kurang penting. Persepsi seseorang akan berkembang atau dapat berubah sesuai informasi baru yang diterimanya dari lingkungannya. 
Analisis Persepsi Pelajar Tingkat Menengah Pada Sekolah Tinggi Agama Islam

\section{Hasil Penelitian}

\section{a. Karakteristik responden}

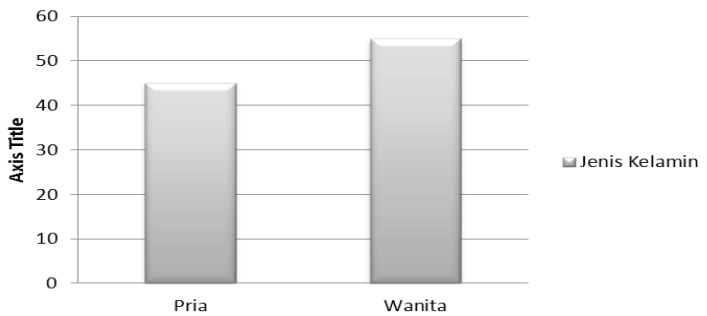

Responden dalam penelitian ini keseluruhannya adalah pelajar tingkat menengah di Kabupaten Kudus dari Madrasah Aliyah maupun Sekolah Menengah Atas. Jumlah keseluruhan sampel yang berhasil terkumpul hingga analisis pengujian kuesioner adalah 100 orang. Pelajar atau peserta didik dalam UU No. 20 tahun 2003 (Sisdiknas) adalah anggota masyarakat yang berusaha mengembangkan potensi diri melalui proses pembelajaran yang tersedia pada jalur, jenjang dan jenis pendidikan tertentu. Sedangkan pengertian jalur pendidikan adalah wahana yang dilalui peserta didik untuk mengembangkan potensi diri dalam suatu proses pendidikan yang sesuai dengan tujuan pendidikan. Jenjang pendidikan adalah tahapan pendidikan yang ditetapkan

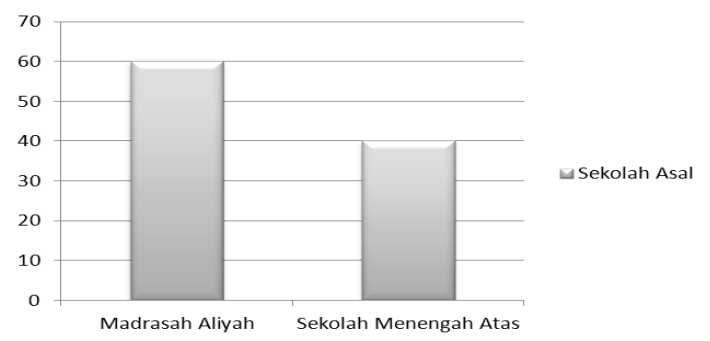

berdasarkan tingkat perkembangan peserta didik, tujuan yang akan dicapai, dan kemampuan yang dikembangkan. Jenis pendidikan adalah kelompok yang didasarkan pada kekhususan tujuan pendidikan suatu satuan pendidikan.

Karakteristik pelajar yang menjadi responden dalam penelitian ini dapat dijelaskan dari sisi karakteristik responden berdasarkan jenis kelamin dan asal sekolah. Jumlah responden pria dan wanita yang 
keseluruhannya berjumlah 100 orang terbagi menjadi 55\% responden (55 orang) berjenis kelamin wanita dan $45 \%$ responden (45 orang) berjenis kelamin pria. Komposisi responden berdasarkan jenis kelamin, dapat dilihat dalam tabel dan grafik berikut:

Karakteristik Responden Berdasarkan Jenis Kelamin

\begin{tabular}{cccc}
\hline No & Jenis kelamin & Jumlah & Persentase \\
\hline 1 & Pria & 45 & $45 \%$ \\
\hline 2 & Wanita & 55 & $55 \%$ \\
\hline & Total & 100 & $100 \%$ \\
\hline
\end{tabular}

\section{Komposisi Responden Berdasarkan Jenis Kelamin}

Adapun komposisi pelajar berdasarkan asal sekolah yaitu: pelajar dari Madrasah Aliyah berjumlah 60 orang sedangkan pelajar dari sekolah menengah berjumlah 40 orang. Komposisi responden dapat dilihat dalam tabel dan grafik berikut:

Tabel Karakteristik Responden Berdasarkan Sekolah Asal

\begin{tabular}{llll}
\hline No & Sekolah & Jumlah & Persentase \\
\hline 1 & Madrasah Aliyah & 60 & $60 \%$ \\
\hline 2 & Sekolah Menengah Atas & 40 & $40 \%$ \\
\hline \multicolumn{2}{l}{ Total } & 100 & $100 \%$ \\
\hline
\end{tabular}

Komposisi Responden Berdasarkan Jenis Sekolah

1) Persepsi Pelajar Tingkat Menengah Terhadap STAIN Kudus

Persepsi merupakan suatu proses yang diawali oleh penginderaan. Penginderaan adalah merupakan suatu proses diterimanya stimulus oleh individu melalui alat penerima yaitu alat indera. Bimo Walgito (2010) mengungkapkan bahwa persepsi adalah suatu kesan terhadap suatu objek yang diperoleh melalui proses penginderaan, pengorganisasian, dan interpretasi terhadap obyek tersebut yang diterima oleh individu, sehingga merupakan suatu yang berarti dan merupakan aktivitas integrated dalam diri individu. Adapun menurut Robbins (2007: 175), persepsi adalah sebuah proses saat individu mengatur dan menginterpretasikan kesan-kesan sensoris mereka guna memberikan arti bagi lingkungan mereka. Perilaku individu seringkali didasarkan pada persepsi mereka tentang kenyataan, bukan pada kenyataan itu sendiri. Istilah persepsi sering dikacaukan dengan sensasi. Sensasi hanya berupa kesan sesaat, 
saat stimulus baru diterima otak dan belum diorganisasikan dengan stimulus lainnya dan ingatan-ingatan yang berhubungan dengan stimulus tersebut.

Untuk mengetahui persepsi pelajar terhadap STAIN Kudus perlu ditetapkan indikator-indikator persepsi yang meliputi:

a) Persepsi mengenai varian program studi

b) Kualitas Dosen dan staf

c) Persepsi mengenai sarana dan prasarana

d) Persepsi mengenai kurikulum (skill yang diberikan)

e) Kualitas lulusan

f) Reputasi STAIN Kudus

Untuk mengetahui tanggapan responden digunakan analisis statistik deskriptif. Statistik deskriptif dimaksudkan untuk menyelidiki keadaan, kondisi atau hal lain-lain yang sudah disebutkan. Kata deskriptif berasal dari bahasa latin yakni descriptives yang berarti uraian, maka penelitian ini berusaha menguraikan, menjelaskan, dan menggambarkan, objek yang akan diteliti. Sedangkan dalam bahasa Inggris 'to describe' yang berarti memaparkan atau menggambarkan sesuatu hal, misalnya: keadaan, kondisi, situasi, peristiwa, kegiatan dan lain-lain.

Hasil analisis deskriptif kuesioner penelitian persepsi menunjukkan bahwa dari semua jenis pertanyaan yang berjumlah 10 item, menunjukkan bahwa rentang jawaban yang dipilih oleh responden berkisar antara nilai minimum 1.00 dan maksimum 4.00, yang menunjukkan bahwa semua alternatif jawaban dipilih oleh responden antara lain: Sangat Setuju, Setuju, Tidak Setuju dan Sangat Tidak Setuju. Rata-rata jawaban yang diberikan oleh responden adalah 29,27 yang berarti rata-rata responden memberikan jawaban "Setuju".

Para pelajar juga memberikan respon yang berbeda untuk masing-masing pertanyaan yang diajukan. Perbedaan secara umum berdasarkan jawaban dari masing-masing item pertanyaan oleh pelajar Madrasah Aliyah dan Sekolah Menengah Atas adalah sebagai berikut:

a) Persepsi mengenai varian program studi

Hampir separo dari jumlah responden pelajar Madrasah Aliyah yang ada memberikan jawaban "Setuju" yaitu sebesar 47\%, 
Rofiq Faudy Akbar

sedangkan 28\% menjawab "Tidak Setuju”, 20\% menjawab "Sangat Setuju" dan sisanya sekitar 5\% memberikan jawaban "Sangat Tidak Setuju”.

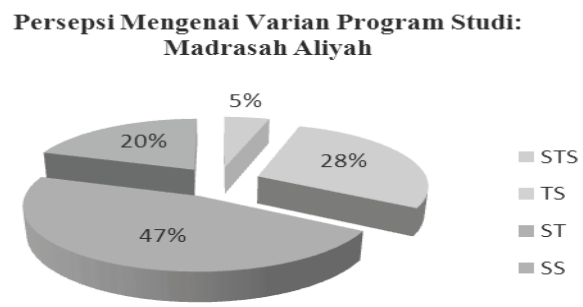

Sedangkan dari pelajar Sekolah Menengah Atas memberikan jawaban "Setuju” sebesar 45\%, menjawab “Tidak Setuju” sebesar 51\%, 3\% menjawab "Sangat Setuju" dan sisanya sekitar 1\% memberikan jawaban "Sangat Tidak Setuju”.

Persepsi Mengenai Varian Program Studi: Sekolah Menengah Atas

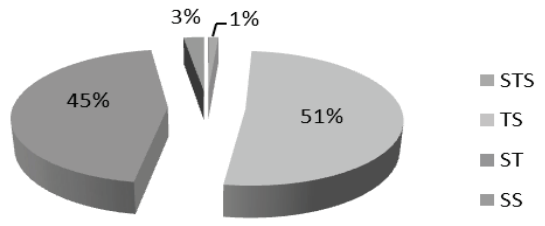

b) Persepsi mengenai kualitas Dosen dan Staf

Pada bentuk pertanyaan kedua ini, responden dari pelajar Madrasah Aliyah hanya memberikan tiga jawaban: Sangat Setuju, Setuju dan Tidak Setuju. Jawaban "Sangat Setuju” 52\%, "Setuju” 38\% dan “Tidak Setuju” 10\%.

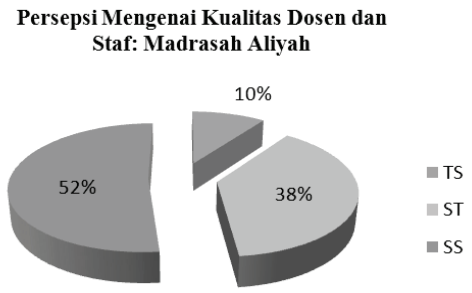

Sedangkan jawaban responden yang berasal dari Sekolah Menengah Atas, untuk jawaban "Setuju” sebesar 60\%, menjawab 
Analisis Persepsi Pelajar Tingkat Menengah Pada Sekolah Tinggi Agama Islam "Tidak Setuju" sebesar 27\%, dan sisanya sekitar 13\% memberikan jawaban "Sangat Setuju”.

Persepsi Mengenai Kualitas Dosen dan Staf: Sekolah Menengah Atas

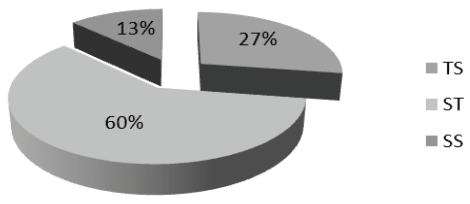

c) Persepsi mengenai sarana dan prasarana yang ada

Delapan puluh tiga persen (83\%) dari pelajar Madrasah Aliyah menganggap bahwa sarana dan prasarana yang ada di STAIN Kudus sudah cukup memadai. Hal ini diketahui dari jawaban responden dengan pilihan "Sangat Setuju" dan "Setuju" sebesar 27\% dan 56\% sedangkan jawaban "Tidak Setuju” dan "Sangat Tidak Setuju” hanya $17 \%$ saja.

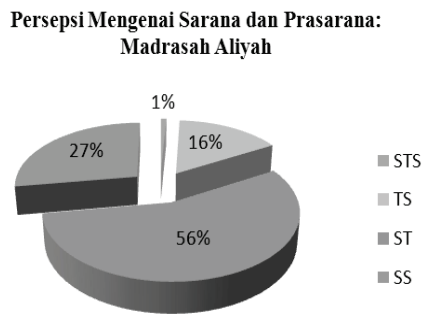

Sedangkan jawaban responden yang berasal dari Sekolah Menengah Atas, untuk jawaban "Setuju” sebesar 75\%, menjawab "Tidak Setuju” sebesar 20\%, dan sisanya sekitar 5\% memberikan jawaban "Sangat Setuju”.

Persepsi Mengenai Kualitas Lulusan: Madrasah Aliyah

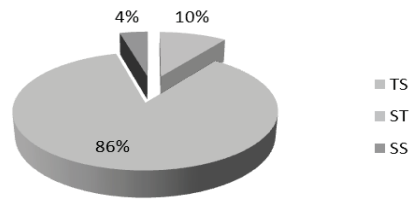

d) Persepsi mengenai kurikulum

Rata-rata responden pelajar Madrasah Aliyah menganggap 
Rofiq Faudy Akbar

kurikulum yang dijalankan di STAIN Kudus sudah bagus dan dapat memberikan keahlian sebagai bekal bersaing di dunia kerja. Hal ini dapat dilihat dari total jawaban responden "Sangat Setuju" dan "Setuju" sebesar 89\%, sedangkan jawaban "Tidak Setuju” hanya $11 \%$ saja.

Persepsi Mengenai Kurikulum: Sekolah Menengah Atas

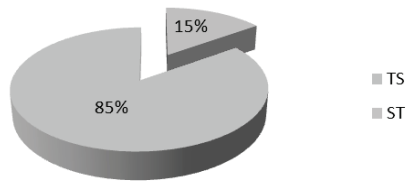

Sedangkan jawaban responden dari Sekolah Menengah Atas, jawaban "Setuju" sebesar 85\%, sedangkan jawaban "Tidak Setuju” $15 \%$.

$$
\begin{gathered}
\text { Persepsi Mengenai Kurikulum: } \\
\text { Madrasah Aliyah }
\end{gathered}
$$

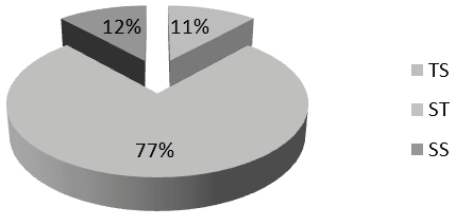

e) Persepsi mengenai kualitas lulusan

Sembilan puluh persen (90\%) pelajar Madrasah Aliyah menyatakan bahwa lulusan perguruan tinggi dan sarjana dari STAIN Kudus dibutuhkan masyarakat dan dapat bersaing di dunia kerja.

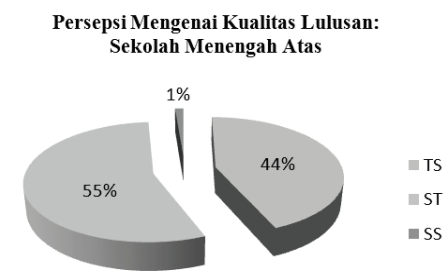

Pelajar dari Sekolah Menengah Atas menyatakan jawaban "Setuju" dan "Sangat Setuju" sebesar 56\% dan "Tidak Setuju" 
Analisis Persepsi Pelajar Tingkat Menengah Pada Sekolah Tinggi Agama Islam sebesar $44 \%$.

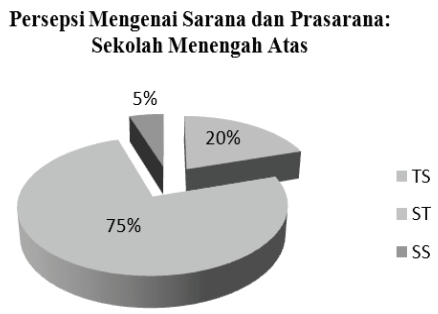

f)Persepsi mengenai reputasi perguruan tinggi

Responden pelajar Madrasah Aliyah memberikan jawaban "Sangat Setuju” sebesar 27\%, jawaban "Setuju” sebesar 35\%, "Tidak Setuju” 35\% dan "Sangat Tidak Setuju” sebesar 3\%.

Persepsi Mengenai Reputasi PTAI:

Madrasah Aliyah

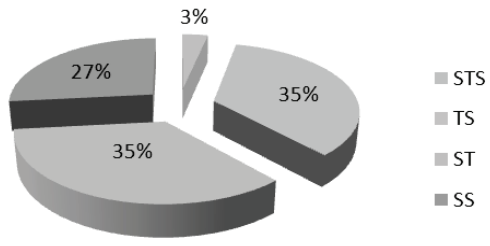

Berbeda dengan pelajar Madrasah Aliyah, pelajar dari Sekolah Menengah Atas memberikan jawaban "Sangat Setuju” sebesar 25\%, jawaban "Setuju" sebesar 20\% dan jawaban tidak setuju sebesar 55\%.

Persepsi Mengenai Reputasi PTAI:

Sekolah Menengah Atas

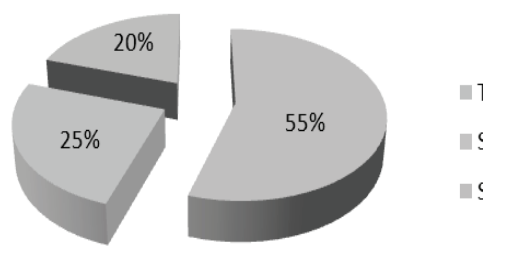




\section{Analisis Persepsi Pelajar Tingkat Menengah terhadap STAIN Kudus}

Secara umum persepsi merupakan kesan seseorang yang dibentuk oleh informasi-informasi dari luar melalui panca indra terhadap suatu objek. Perilaku individu seringkali didasarkan pada persepsi mereka tentang kenyataan, bukan pada kenyataan itu sendiri. Istilah persepsi sering dikacaukan dengan sensasi. Sensasi hanya berupa kesan sesaat, saat stimulus baru diterima otak dan belum diorganisasikan dengan stimulus lainnya dan ingatan-ingatan yang berhubungan dengan stimulus tersebut. Untuk mengetahui persepsi seseorang terhadap suatu objek perlu diperhatikan indikatorindikator persepsi yang meliputi: penyerapan terhadap rangsang atau objek dari luar individu, pengertian atau pemahaman dan penilaian atau evaluasi.

Analisis persepsi pelajar tingkat menengah terhadap STAIN Kudus menunjukkan adanya perbedaan. Perbedaan persepsi pelajar Madrasah Aliyah dan pelajar Sekolah Menengah Atas terhadap STAIN Kudus dapat dideskripsikan sebagai berikut: Pertama, pertanyaan mengenai varian program studi, pelajar Madrasah Aliyah menilai bahwa varian program studi yang ada di STAIN Kudus sudah sangat variatif. Hal ini ditunjukkan dengan tingginya total jawaban "Setuju" dan "Sangat Setuju" yaitu sebesar 67\%. Adapun pelajar dari Sekolah Menengah Atas berpandangan lain mengenai varian program studi yang ada di STAIN Kudus, para pelajar menganggap varian program studi yang ada di STAIN Kudus belum begitu variatif. Hal ini ditunjukkan dengan total jawaban "Tidak Setuju” dan "Sangat Tidak Setuju” sebesar 52\%.

Dimensi persepsi selanjutnya adalah kualitas dosen dan staf/ pegawai. Pada bentuk pertanyaan kedua ini, baik responden dari pelajar Madrasah Aliyah maupun pelajar dari Sekolah Menengah Atas sama-sama memberikan respon positif bahwa kualitas Dosen dan staf/pegawai telah sesuai standar yang ditetapkan atau diharapkan oleh masyarakat. Sebesar 90\% pelajar Madrasah Aliyah memilih jawaban "Sangat Setuju” dan "Setuju”, dan sebesar 73\% dari pelajar Sekolah Menengah Atas.

Dalam hal sarana prasarana, delapan puluh tiga persen (83\%) dari pelajar Madrasah Aliyah menganggap bahwa sarana 
dan prasarana yang ada di STAIN Kudus sudah cukup memadai. Sedangkan jawaban responden yang berasal dari Sekolah Menengah Atas sebesar 80\%.

Indikator yang keempat adalah persepsi mengenai kurikulum. Rata-rata responden pelajar Madrasah Aliyah menganggap kurikulum yang dijalankan di STAIN Kudus sudah bagus dan dapat memberikan keahlian sebagai bekal bersaing di dunia kerja. Hal ini dapat dilihat dari total jawaban responden "Sangat Setuju" dan "Setuju" sebesar $89 \%$, sedangkan jawaban "Tidak Setuju” hanya 11\% saja. Sedangkan jawaban responden dari Sekolah Menengah Atas, jawaban "Setuju” sebesar $85 \%$, sedangkan jawaban "Tidak Setuju” 15\%.

Adapun mengenai kualitas lulusan, sembilan puluh persen (90\%) pelajar Madrasah Aliyah menyatakan bahwa lulusan perguruan tinggi dan sarjana dari STAIN Kudus dibutuhkan masyarakat dan dapat bersaing di dunia kerja. Sedangkan pelajar dari Sekolah Menengah Atas menyatakan jawaban "Setuju" dan "Sangat Setuju" sebesar 56\% dan "Tidak Setuju” sebesar 44\%.

Pertanyaan terakhir adalah persepsi mengenai reputasi atau popularitas perguruan tinggi. Reputasi bisa diartikan sebagai nama baik. Nama baik tersebut bukan kita yang menyematkan namun orang lain yang telah memberikan penilaian tentang kita. Jika dikatakan reputasi kita baik, bukan berarti kita yang menilai diri kita sendiri tapi orang lain yang menilai setelah melihat perbuatan kita. Kata reputasi bisa juga berarti popularitas, bila dihubungkan dengan Perguruan Tinggi kata reputasi dapat pula berarti popularitas Perguruan Tinggi disamping Perguruan-Perguruan Tinggi lainnya. Popularitas atau reputasi disini lebih berkaitan dengan kecenderungan pelajar untuk menetapkan pilihan dalam melanjutkan studi. Berdasarkan pertanyaan mengenai reputasi, responden pelajar Madrasah Aliyah memberikan jawaban "Sangat Setuju” dan "Setuju” sebesar 62\%, jawaban "Tidak Setuju” dan "Sangat Tidak Setuju” sebesar 38\%. Pelajar dari Sekolah Menengah Atas memberikan jawaban "Sangat Setuju” dan "Setuju" sebesar $45 \%$ dan jawaban tidak setuju sebesar $55 \%$.

Berdasarkan analisis melalui indikator-indikator persepsi yang ditetapkan dalam penelitian ini, dapat diketahui bahwa perbedaan persepsi dipengaruhi oleh ketidaksamaan penyerapan atau rangsangan yang diterima, kurangnya pemahaman atau pengertian 
sehingga menentukan penilaian atau evaluasi. Persepsi terhadap suatu institusi atau lembaga pendidikan bisa dikatakan sangat variatif. Hal ini dikarenakan institusi pendidikan sebagai suatu organisasi yang menjual produk berupa jasa bukan berupa barang. Bentuk produk yang berupa jasa ini menjadikan penilaian yang berbeda mengenai ukuran tingkat kepuasan atau kualitas layanan yang diberikan.

Dengan kata lain akan sangat sulit untuk menetapkan standar baku kepuasan atau kualitas layanan. Untuk itu suatu institusi yang menjual produk berupa jasa harus selalu melakukan inovasi untuk memenuhi kebutuhan pelanggan. Perguruan Tinggi sebagai salah satu organisasi yang menawarkan jasa di bidang pendidikan, harus membangun persepsi masyarakat bahwa kualitas layanan yang diberikan dan produk yang dihasilkan dapat memenuhi ekspektasi masyarakat.

\section{Simpulan}

Analisis persepsi pelajar tingkat menengah terhadap STAIN Kudus menunjukkan adanya perbedaan. Perbedaan persepsi pelajar Madrasah Aliyah dan pelajar Sekolah Menengah Atas terhadap STAIN Kudus dapat dideskripsikan dari indikator-indikator yang digunakan dalam penelitian. Berdasarkan analisis melalui indikator-indikator persepsi yang ditetapkan dalam penelitian ini, dapat diketahui bahwa perbedaan persepsi dipengaruhi oleh ketidaksamaan penyerapan atau rangsangan yang diterima, kurangnya pemahaman atau pengertian sehingga menentukan penilaian atau evaluasi. Persepsi terhadap suatu institusi atau lembaga pendidikan bisa dikatakan sangat variatif. 
Analisis Persepsi Pelajar Tingkat Menengah Pada Sekolah Tinggi Agama Islam

\section{DAFTAR PUSTAKA}

Arikunto, Suharsimi. 2010. Prosedur Penelitian: Suatu Pendekatan Praktik. Jakarta: Rineka Cipta.

Davidoff, LL. 1988. Introduction to Psychology, alih bahasa Mari Juniati, Psikologi Suatu Pengantar Jilid I. Jakarta: Erlangga.

Gibson, Ivancevich Donelly. 1989. Organisasi dan Manajemen Perilaku, Struktur dan Proses. (editor: Agus Dharma, SH, M, Ed), Jakarta: Erlangga.

Robbins, Stephen P. 2007. Perilaku Organisasi Buku 1. Jakarta: Salemba Empat.

Spradley, J.P. 1980. Participant Observation. New York: Holt, Rinehart, and Winston.

Sugiyono, 2012. Metode Penelitian Pendidikan. Bandung: Alfabeta.

Sutopo, H.B. 1995. Kritik Seni Holistik Sebagai Model Pendekatan Penelitian Kualitatif. Surakarta: UNS Press.

Taylor, Shelley E.dkk. 2009. Psikologi Sosial, Jakarta: Kencana.

Walgito, Bimo. 2010. Pengantar Psikologi Umum. Yogyakarta: Andi. 
halaman ini bukan sengaja dikosongkan 